\title{
Analisis Pelatihan, Disiplin Kerja, Remunerasi, dan Motivasi Berprestasi dengan Kepuasan Kerja Sebagai Variabel Intervening terhadap Kinerja Karyawan
}

\author{
Abd. Rasyid Syamsuri ${ }^{*}$, Zulkifli Musannip Efendi Siregar ${ }^{2}$, \\ ${ }^{1,2}$ Sekolah Tinggi Ilmu Ekonomi Labuhan Batu: Rantau Prapat \\ abd.rasyidsyamsuri@gmail.com
}

\begin{abstract}
This study aims to analyze the training, work discipline, remuneration, achievement motivation with job satisfaction as an intervening variable on employee performance. Research respondents are the employees PT. Plantation Milano Panai Tengah Labuhanbatu of 61 respondents with sampling using slovin formula. Sources and data collection techniques used in this study are primary data, to wit data obtained or collected directly from the source data through interviews and a list of questions given to the respondents. The data analysis technique used SEM (Stuctural Equation Modeling) with SmartPLS program. R square value is known that job satisfaction variable and employee performance can be explained by training variables, work discipline, remuneration and achievement motivation equal to $67,8 \%$, and $61,2 \%$. The result of Path Coefficients with Statistics (O / STDEV) used to examine the analysis of training, work discipline, remuneration, achievement motivation on employee performance with job satisfaction as intervening variable. The results showed that the training had positive and insignificant effect on job satisfaction. Discipline has positive and insignificant effect on job satisfaction. Remuneration has a positive and insignificant effect on job satisfaction. Achievement motivation has a positive and significant impact on job satisfaction. Training has a positive and insignificant effect on employee performance. Achievement motivation has positive and insignificant effect on employee performance and job satisfaction have positive and significant effect to employee performance.
\end{abstract}

Keywords: Training, Work Discipline, Remuneration, Achievement Motivation, Job Satisfaction, Employee Performance

\begin{abstract}
Abstrak
Penelitian ini bertujuan untuk menganalisis pelatihan, disiplin kerja, remunerasi, motivasi berprestasi dengan kepuasan kerja sebagai variabel intervening terhadap kinerja karyawan. Responden penelitian adalah para karyawan PT. Perkebunan Milano Panai Tengah Labuhanbatu sebanyak 61 responden dengan pengambilan sampel yang menggunakan rumus slovin. Sumber dan teknik pengumpulan data yang digunakan dalam penelitian ini adalah data primer, yaitu data yang diperoleh atau dikumpulkan secara langsung dari sumber datanya melalui wawancara dan daftar pertanyaan yang diberikan kepada responden. Teknik analisis data penelitian ini menggunakan SEM (Stuctural Equation Modelling) dengan program SmartPLS. Nilai $R$ square diketahui bahwa variabel kepuasan kerja dan kinerja karyawan dapat dijelaskan oleh variabel pelatihan, disiplin kerja, remunerasi dan motivasi berprestasi sebesar 67,8\%, dan 61,2 \%. Hasil Path Coefficients dengan $t$ Statistics $(O / S T D E V)$ yang digunakan untuk meneliti analisis pelatihan, disiplin kerja, remunerasi, motivasi berprestasi terhadap kinerja karyawan dengan kepuasan kerja sebagai variabel intervening. Hasil penelitian menunjukkan bahwa Pelatihan berpengaruh positif dan tidak signifikan terhadap kepuasan kerja. Disiplin berpengaruh positif dan tidak signifikan terhadap kepuasan kerja. Remunerasi berpengaruh positif dan tidak signifikan terhadap kepuasan kerja. Motivasi Berprestasi berpengaruh positif dan signifikan terhadap kepuasan kerja. Pelatihan berpengaruh positif dan tidak signifikan terhadap kinerja karyawan. Motivasi Berprestasi berpengaruh positif dan tidak signifikan terhadap kinerja karyawan serta kepuasan kerja berpengaruh positif dan signifikan terhadap kinerja karyawan.
\end{abstract}

Kata kunci : Pelatihan, Disiplin Kerja, Remunerasi, Motivasi Berprestasi, Kepuasan Kerja, Kinerja Karyawan 


\section{Pendahuluan}

\subsection{Latar Belakang}

Manajemen berhubungan dengan suatu usaha untuk mencapai sasaran-sasaran tertentu dengan jalan menggunakan sumber-sumber yang telah tersedia dengan sebaik-baiknya, sumber yang paling penting dalam setiap organisasi adalah Sumber Daya Manusia (SDM), (Syamsuri, 2012). Manajemen Sumber Daya Manusia salah satu faktor kunci untuk mendapatkan kinerja terbaik. Setiap perusahaan berkepentingan terhadap kinerja terbaik yang mampu dihasilkan oleh rangkaian sistem yang berlaku dalam organisasi tersebut. Untuk itu masalah sumber daya manusia merupakan masalah yang penting dari keseluruhan tingkat perencanaan sampai dengan evaluasi yang memanfaatkan sumber daya manusia tersebut. Hal ini termasuk dalam mewujudkan pelatihan, disiplin kerja, remunerasi, motivasi berprestasi, kepuasan kerja dan kinerja yang dilakukan para anggota organisasinya dalam pencapaian tujuan yang telah ditetapkan. Tujuan ini dapat dicapai apabila organisasi didukung oleh sumber daya manusia yang baik, memiliki performa kerja yang tinggi dan sumber daya manusia yang berkompeten di dalam pekerjaan.

PT. Perkebunan Milano Panai Tengah Labuhanbatu merupakan perusahaan swasta milik nasional yang bergerak dalam bidang industri dan perkebunan kelapa sawit. Perusahaan merekrut Sumber Daya Manusia (SDM) berkualitas secara selektif dalam hal pelatihan, disiplin kerja, remunerasi, motivasi berprestasi, kepuasan kerja dan kinerja bagi para karyawan secara bersungguh-sungguh dan berkesinambungan. PT. Perkebunan Milano Panai Tengah Labuhanbatu mempunyai tujuan untuk mengembangkan usahanya, mempertahankan hidup, dan menghasilkan laba, sebagai alat ukur keberhasilan dalam menjalankan usaha. Di samping itu juga PT. Perkebunan Milano mendatangkan ahli-ahli dari luar Negeri dengan tujuan utama memacu karyawan agar dapat berkembang dengan pesat.

Dalam meningkatkan keunggulan sumber daya manusia perusahaan diharuskan melaksanakan program pelatihan yang efektif diberikan sesuai dengan bidang tugas yang dibutuhkan dalam melaksanakan pekerjaan, sehingga kemampuan karyawan dapat meningkat. Pelatihan menjadi hal yang sangat penting dilakukan oleh perusahaan sehingga tenaga kerja atau karyawan memiliki pengetahuan (knowledge), kemampuan (ability), dan keterampilan (skill) yang dapat memenuhi kebutuhan perusahaan di masa kini dan di masa yang akan datang. Berdasarkan survey dan obsevasi yang dilakukan penulis fenomena yang terjadi dalam pelaksanaan program pelatihan di PT. Perkebunan Milano Panai Tengah Labuhanbatu para karyawan di dalam organisasi belum memperoleh kesempatan yang sama untuk mengikuti program pelatihan. Peserta yang mengikuti program pelatihan cenderung adalah peserta yang sama. Kejadian ini mengakibatkan peningkatan keunggulan yang tidak merata, atau dengan kata lain karyawan yang tidak diberikan kesempatan untuk mengikuti program pelatihan tidak dapat meningkatkan keunggulan mereka dalam bidang pekerjaan yang mereka lakukan.

Karyawan yang memiliki disiplin yang baik maka akan tercapai suatu keuntungan yang berguna, baik bagi PT. Perkebunan Milano Panai Tengah Labuhanbatu maupun bagi karyawan itu sendiri. Fenomena yang terjadi mengenai disiplin di PT. Perkebunan Milano Panai Tengah Labuhanbatu cukup banyak kesenjangan yang kurang sesuai, masih ada beberapa kelemahan yang masih ditunjukkan oleh karyawan dalam disiplin kerja. Disiplin yang ditinjau dari preventif, korektif, dan progresif belum terlaksana dengan baik. Dari survey penulis, masih ada karyawan yang tidak tepat waktu sewaktu masuk kantor, menunda tugas kantor, kurang disiplin waktu, ada yang tidak menggunakan kelengkapan pakaian seragam sesuai dengan ketentuan yang berlaku. Ketidakhadiran karyawan atau tingkat absensi yang cukup tinggi ini dipengaruhi oleh rendahnya disiplin karyawan dalam organisasional dan juga disebabkan oleh rendahnya rasa tanggung jawab karyawan 
Remunerasi menjadi salah satu program reformasi birokrasi. Pemberian remunerasi ini mulai diberlakukan di indonesia pada tahun 2007. Penetapan remunerasi umumnya berupa gaji, honorarium, tunjangan, bonus, insentif, pesangon dan pensiun. Adanya pemberian remunerasi tersebut bermanfaat bagi organisasi maupun karyawan, program pemberian remunerasi ini sendiri merupakan cara yang paling sukses dalam meningkatkan kinerja karywan karena berhubungan langsung antara kinerja dan imbalan. Pemberian remunerasi ini diharapkan dapat membentuk kondisi yang membuat karyawan termotivasi dalam memberikan kontribusi terhadap suatu organisasi atau perusahaan. Berdasarkan survey, permasalahan yang terjadi di PT. Perkebunan Milano Panai Tengah Labuhanbatu yaitu adanya berbagai kendala yang dihadapi oleh para karyawan mengenai remunerasi. Para karyawan belum memenuhi sistem remunerasi yang memenuhi asas keadilan dari faktor internal, dalam arti pekerjaan yang lebih berat selayaknya memperoleh besaran remunerasi yang lebih tinggi, sedangkan faktor eksternal dalam arti kesetaraannya dengan remunerasi diperusahaan atau organisasi lain.

Motivasi berprestasi menjadi perilaku dorongan seseorang untuk melakukan pekerjaan dengan baik dan kinerja yang tinggi. Kebutuhan akan berprestasi tinggi timbul pada diri seseorang untuk berupaya mencapai target yang telah ditetapkan, bekerja keras demi mencapai keberhasilan dan memiliki keinginan untuk mengerjakan sesuatu secara lebih baik dari sebelumnya. Karyawan dengan motivasi berprestasi tinggi sangat menyukai tantangan, berani mengambil risiko, sanggup mengambil alih tanggungjawab, senang bekerja keras. Dorongan ini akan menimbulkan kebutuhan berprestasi karyawan yang membedakan dengan yang lain, karena selalu ingin mengerjakan sesuatu yang lebih baik. Hal ini menunjukkan bahwa motivasi berprestasi juga merupakan faktor yang perlu untuk diperhatikan dalam usaha mencapai kinerja yang tinggi. Rendahnya motivasi karyawan untuk berprestasi juga menjadi permasalahan pada perusahaan atau organisasi. Hal ini terlihat bahwa motivasi berprestasi karyawan PT. Perkebunan Milano Panai Tengah Labuhanbatu masih kurang, survey yang telah dilakukan menunjukkan banyaknya karyawan yang menunda-nunda pekerjaan sehingga gagal mencapai target yang ditetapkan. PT. Perkebunan Milano Panai Tengah Labuhanbatu menerapkan sistem penalti kesemua bagian pakerjaan. Penalti yang diberikan oleh perusahaan adalah berupa adanya pengurangan insentif (termasuk dalam penetapan remunerasi).

Kepuasan kerja pada dasarnya merupakan sesuatu yang bersifat individual. Setiap individu memiliki tingkat kepuasan yang berbeda-beda sesuai dengan sistem nilai yang berlaku pada dirinya. Semakin tinggi penilaian terhadap kegiatan dirasakan sesuai dengan keinginan individu, maka semakin tinggi kepuasannya terhadap kegiatan tersebut. Dengan demikian, kepuasan merupakan evaluasi yang menggambarkan seseorang atas perasaan sikapnya senang atau tidak senang, puas atau tidak puas dalam bekerja, (Rivai, 2008). Dari survey yang dilakukan penulis di PT. Perkebunan Milano Panai Tengah Labuhanbatu, kepuasan kerja para karyawan belum mereka dapatkan sesuai dengan yang diharapkan para karyawan tersebut. Hal ini dilihat dari beberapa posisi karyawan yang tidak sesuai dengan latar belakang pendidikan yang berdampak pada jenjang karir dan masa depan untuk mereka. Karyawan akan merasa puas apabila ia mendapatkan apa yang dibutuhkannya.

Kinerja yang tercapai sesuai dengan tujuan yang ditetapkan menjadi suatu hasil kegiatan sumber daya manusia yang ada dalam perusahaan dan secara bersama-sama membawa hasil akhir yang didasarkan pada tingkat mutu dan standar yang telah ditetapkan. Tuntutan akan kinerja yang tinggi memang sudah menjadi bagian dari perusahaan, namun pada kenyataannya belum semua karyawan memiliki kinerja yang tinggi sesuai dengan yang diharapkan oleh perusahaan. Pada hakikatnya kinerja perusahaan sangat bergantung pada kinerja karyawan, yang memberikan kontribusi positif pada hasil akhir yang diharapkan. Hasil kerja secara kualitas dan kuantitas yang dicapai oleh karyawan dilaksanakan sesuai dengan tanggung jawab yang diberikan. Oleh sebab 
itu kinerja karyawan memiliki peranan yang penting untuk keberlangsungan tujuan perusahaan. Berdasarkan fenomena dan latar belakang permasalahan tersebut, judul penelitian ini membahas mengenai "Analisis Pelatihan, Disiplin Kerja, Remunerasi, dan Motivasi Berprestasi Dengan Kepusan Kerja Sebagai Variabel Intervening Terhadap Kinerja Karyawan”.

\subsection{Uraian Teori}

Menurut (Ivancevich, Konopaske \& Matteso, 2009), pelatihan adalah proses sistematis untuk mengubah perilaku karyawan, yang diarahkan untuk mencapai tujuan-tujuan organisasi. Pelatihan terkait dengan keterampilan dan kemampuan pekerjaan saat ini. Orientasinya adalah membantu karyawan mengawasi keterampilan dan kemampuan spesifik agar berhasil dalam pekerjaan. Pelatihan juga mengajarkan karyawan baru atau yang ada sekarang, keterampilan dasar mereka butuhkan untuk menjalankan suatu pekerjaan. Dimensi program pelatihan yang efektif dapat diberikan perusahaan kepada karyawannya. Menurut (Ivancevich, Konopaske \& Matteso 2009), dimensi program pelatihan yang efektif dapat diukur melalui 1) Isi pelatihan, yaitu apakah isi program pelatihan relevan dan sejalan dengan kebutuhan pelatihan, dan pelatihan tersebut up to date. 2) Metode pelatihan, apakah metode pelatihan yang diberikan sesuai untuk subjek itu dan apakah metode pelatihan tersebut sesuai dengan gaya peserta pelatihan. 3) Sikap dan keterampilan instruktur, yaitu apakah instruktur mempunyai sikap dan keterampilan yang mendorong orang untuk belajar. 4) Lama waktu pelatihan, yaitu berapa lama waktu pemberian materi pokok yang harus dipelajari dan seberapa cepat tempo penyampaian materi tersebut. 5) Fasilitas pelatihan, yaitu apakah tempat penyelenggaraan pelatihan dapat dikendalikan oleh instruktur, apakah relevan dengan jenis pelatihan.

Menurut (Handoko, 2012), Disiplin adalah kegiatan manajemen untuk menjalankan standar-standar organisasional". Standar-standar organisasional tersebut terdiri dari tiga tipe kegiatan pendisiplinan yaitu 1) Disiplin Preventif (Preventive discipline), merupakan tindakan yang diambil untuk mendorong karyawan mengikuti atau mematuhi norma-norma dan aturanaturan sehingga penyelewengan-penyelewengan tidak terjadi. Tujuannya adalah untuk mendorong disiplin diri diantara para karyawan, dengan cara ini karyawan menjaga disiplin diri mereka. 2) Disiplin Korektif (Corrective discipline), merupakan suatu kegiatan yang diambil untuk menangani pelanggaran terhadap aturan-aturan dan mencoba untuk menghindari pelanggaran-pelanggaran lebih lanjut. Kegiatan korektif sering berupa suatu bentuk hukuman dan disebut tindakan pendisiplinan (disciplinary action). Sebagai contoh tindakan pendisiplinan berupa peringatan atau skorsing. 3) Disiplin Progresif (Progresive dicipline) adalah suatu kebijakan disiplin yang memberikan hukuman-hukuman yang lebih berat terhadap pelanggaranpelanggaran yang berulang. Tujuannya adalah memberikan kesempatan kepada pegawai untuk mengambil tindakan korektif sebelum hukuman-hukuman yang lebih serius dilaksanakan. Disiplin progresif juga memungkinkan pimpinan untuk membantu pegawai memperbaiki kesalahan.

(Syamsuri, 2012), berdasarkan tipe disiplin, dapat diketahui bahwa indikator disiplin preventif dapat 1) Mendorong pegawai bekerja sesuai peraturan organisasi dan 2) Bertindak sesuai dengan norma-norma. Untuk disiplin korektif 1) Menerima sanksi-sanksinya apabila melanggar tugas yang diberikan 2) Melaksanakan pekerjaan dengan sebaik-baiknya, sedangkan disiplin progresif 1) Memberikan hukuman berat terhadap pelanggaran yang berulang 2) Membantu memperbaiki kesalahan atas pelanggaran yang dilakukan.

Dalam konteks perusahaan, Remunerasi diartikan sebagai suatu tindakan balas jasa atau imbalan yang diterima karyawan/pekerja dari pengusaha atas prestasi yang diberikan pekerja dalam rangka mewujudkan tujuan perusahaan (Pora, 2011). Suatu organisasi atau perusahaan harus secara efektif memberikan remunerasi sesuai dengan prestasi yang mereka berikan. 
Pemberian remunerasi kepada karyawan perlu mendapat perhatian khusus dari fihak manajemen agar pekerjaan-pekerjaan yang dilakuka para karyawan dapat akan terus meningkat. Komponen remunerasi menurut (Pora, 2011) adalah sebagi berikut : 1) Gaji, merupakan balas jasa dalam bentuk uang yang diberikan kepada karyawan atas tenaga dan pikiran yang telah disumbangkan dalam rangka memajukan atau mewujudkan tujuan perusahaan. Gaji sifatnya tetap dan diberikan dalam jumlah yang pasti selama masih ada hubungan kerja, maka gaji dapat diterima oleh karyawan yang berstatus karyawan tetap berdasarkan perhitungan bulanan. 2) Insentif merupakan bentuk kompensasi berorientasi pada hasil kerja dan merupakan salah satu faktor penting untuk memotivasi pekerja agar lebih bersemangat demi tercapainya tujuan organisasi. Insentif merupakan imbalan langsung yang dibayarkan kepada karyawan atas prestasi kerjanya yang mencapai atau melebihi target yang telah ditentukan. 3) Benefit, hal-hal yang termasuk kategori benefit adalah service (pelayanan) dan ketersedian fasilitas-fasilitas. Berbeda dengan insentif, benefit merupakan imbalan tidak langsung atau tambahan baik dalam bentuk uang maupun nonfinansial yang diberikan pengusaha kepada karyawan 4) Bonus atau Komisi adalah imbalan yang diterima karyawan dari pengusaha atas pencapain kinerja yang melampaui hasil atau waktu yang ditetapkan. Dalam praktiknya, pemberian bonus dapat berupa uang cash, naik haji, umroh,tour dalam/luar negeri, gaji bulan ke tigabelas atau ke empatbelas dan kredit atau pinjaman lunak 5) Tunjangan, suatu pembayaran yang diatur berkaitan dengan pekerjaan yang diberikan oleh pengusaha kepada pekerja.

Istilah Need for achievement pertama kali dipopulerkan oleh Mc Clelland dengan sebutan $n$-ach sebagai singkatan dari need for achievement. Mc Clelland menganggap $n$-ach sebagai virus mental. Virus mental tersebut merupakan suatu pikiran yang berhubungan dengan bagaimana melakukan sesuatu dengan baik, lebih cepat lebih efisien dibanding dengan apa yang telah dilakukan sebelumnya. Menurut Mc Clelland dalam (Mangkunegara, 2007) pengertian motivasi berprestasi didefenisikan sebagai usaha mencapai sukses atau berhasil dalam kompetisi dengan suatu ukuran keunggulan yang dapat berupa prestasi orang lain maupun prestasi sendiri.

Mc Clelland dalam (Mangkunegara, 2007) mengemukakan enam karakteristik orang yang mempunyai motivasi berprestasi tinggi, yaitu 1) Memiliki tingkat tanggung jawab pribadi yang tinggi. 2) Berani mengambil dan memikul resiko 3) Memiliki tujuan realistik. 4) Memiliki rencana kerja yang menyeluruh dan berjuang untuk merealisasikan tujuan. 5) Memanfaatkan umpan balik yang konkrit dalam semua kegiatan yang dilakukan. 6) Mencari kesempatan untuk merealisasikan rencana yang telah diprogramkan. Teori motivasi prestasi, Mc Clelland mengemukakan bahwa individu mempunyai cadangan energi potensial, bagaimana energi ini dilepaskan dan dikembangkan tergantung pada kekuatan atau dorongan motivasi individu dan situasi serta peluang yang tersedia.

(Robbins dan Judge, 2008) mendefinisikan kepuasan kerja sebagai suatu perasaan positif tentang pekerjaan seseorang yang merupakan hasil dari evaluasi karakteristik-karakteristiknya. Karyawan secara individual mempunyai kepuasan kerja yang berbeda, sekalipun berada dalam tipe pekerjaan yang sama hal ini tergantung tingkat kebutuhannya dan sistem yang berlaku pada dirinya. Menurut (Robbins dan Judge, 2008) bahwa faktor-faktor yang mendorong kepuasan kerja adalah 1). Ganjaran yang pantas 2) Pekerjaan itu sendiri 3) Rekan kerja yang mendukung 4) Kesesuaian kepribadian-pekerjaan.

(Dessler, 2009) mendefinisikan kinerja sebagai evalusi pekerjaan karyawan saat ini atau dimasa lalu relatif terhadap standar prestasinya. Bernardin dan Russel dalam (Gomes, 2003) "A way of measuring the contribution of individuals to their organization" (Kinerja adalah cara mengukur kostribusi karyawan kepada organisasi tempat mereka bekerja). Model kinerja yang dicontohkan oleh (Dessler, 2009) meliputi indikator sebagai berikut: 1) Kualitas kerja adalah akurasi, ketelitian,dan bisa diterima atas pekerjaan yang dilakukan. 2) Produktivitas adalah 
kuantitas dan efisiensi kerja yang dihasilkan dalam periode waktu tertentu. 3) Pengetahuan pekerjaan adalah keterampilan dan informasi praktis/teknis yang digunakan pada pekerjaan. 4) Bisa diandalkan adalah seorang karyawan bisa diandalkan atas penyelesaian dan tindak lanjut tugas. 5) Kehadiran adalah seorang karyawan tepat waktu, mengamati periode istirahat/makan yang ditentukan dan catatan kehadiran secara keseluruhan. 6) Kemandirian adalah suatu pekerjaan yang dilakukan dengan atau tanpa pengawasan. Kinerja dapat menunjukkan tingkat kemampuan pelaksanaan tugas-tugas organisasi. Selain itu, kinerja juga menunjukkan tujuan yang dinyatakan dalam petunjuk hasil dapat dicapai oleh suatu organisasi. Keberhasilan kinerja sebenarnya sangat ditentukan oleh kinerja yang baik, kesatuan dan persamaan persepsi dari seluruh karyawan serta memahami cara menjalankan tugas dan pekerjaan dalam suatu sistem manajemen dalam suatu organisasi. Dari beberapa uraian teori yang telah dikemukakan, model kerangka konseptual pada penelitian ini adalah :

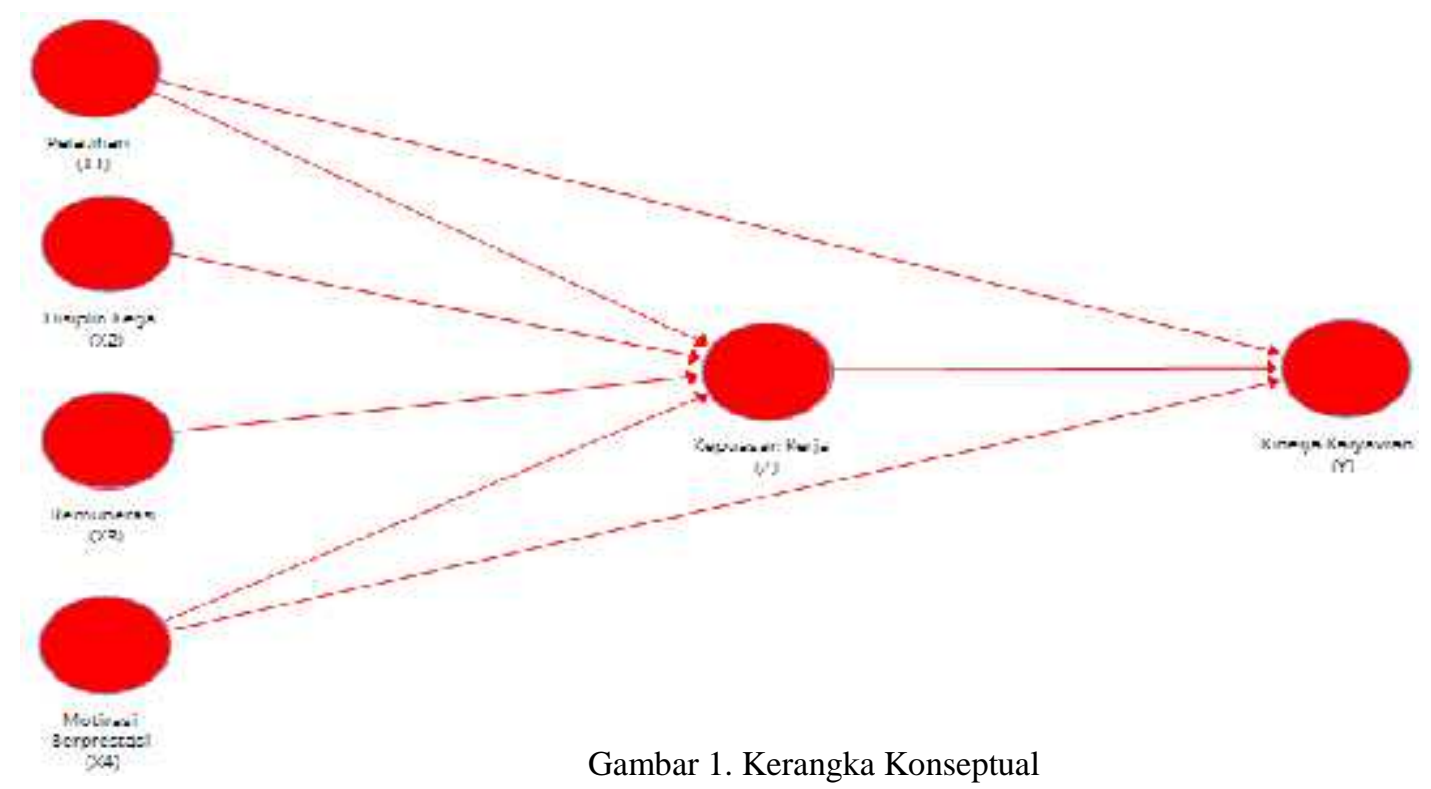

Untuk hipotesis dalam penelitian ini sebagai berikut : a) Pelatihan berpengaruh positif dan signifikan terhadap Kepuasaan kerja, b) Disiplin kerja berpengaruh positif dan signifikan terhadap Kepuasaan kerja, c) Remunerasi berpengaruh positif dan signifikan terhadap Kepuasaan kerja, d) Motivasi berprestasi berpengaruh positif dan signifikan terhadap Kepuasaan kerja, e) Pelatihan berpengaruh positif dan signifikan terhadap Kinerja karyawan, f) Motivasi berprestasi berpengaruh positif dan signifikan terhadap Kinerja karyawan dan g) Kepuasaan kerja karyawan berpengaruh positif dan signifikan terhadap Kinerja karyawan

\section{Metodologi}

\subsection{Jenis dan Sifat Penelitian}

Penelitian ini dilakukan di PT. Perkebunan Milano Panai Tengah yang beralamat di Cabang Dua Desa Sei Nahodaris Kecamatan Panai Tengah Labuhanbatu. Jenis penelitian ini berupa deskriptif kuantitatif yaitu penelitian yang mengukur kekuatan hubungan antara dua variabel atau lebih. Menurut (Arikunto, 2012)'Penelitian deskriptif kuantitatif adalah meliputi pengumpulan data untuk menguji hipotesis atau menjawab mengenai status terakhir dari subjek penelitian". Adapun sifat penelitian ini adalah penelitian penjelasan (deskriptif eksplanatori). 


\subsection{Populasi dan Sampel}

Populasi adalah wilayah generalisasi yang terdiri atas objek atau subjek yang mempunyai kualitas dan karakteristik kemudian ditarik kesimpulan (Sugiyono, 2011). Populasi dalam penelitian ini adalah seluruh karyawan yang ada pada PT Perkebunan Milano Panai Tengah Labuhanbatu yang berjumlah 159 orang. Menurut (Sugiyono, 2011) sampel adalah bagian dari jumlah dan karakteristik yang dimiliki oleh populasi tersebut. Untuk menentukan minimal sampel yang dibutuhkan jika ukuran populasi diketahui, dapat digunakan rumus Slovin:

$$
\mathrm{n}=\frac{N}{1+N e^{2}}
$$

\section{Keterangan :}

$$
\begin{array}{ll}
\mathrm{n} & =\text { jumlah sampel } \\
\mathrm{N} & =\text { jumlah populasi } \\
\mathrm{e} & =\text { tingkat kesalahan (persen kelonggaran ketidaktelitian karena kesalahan penarikan } \\
& \text { sampel). }
\end{array}
$$

Populasi (N) sebanyak 159 orang dan tingkat kesalahan (e) sebesar 10\% besarnya sampel adalah :

$n=\frac{159}{1+159 \times 0,10^{2}}=61,38$, maka sampel dibulatkan menjadi 61 Orang. Sampel yang akan diambil dari populasi menggunakan convenience sampling, yaitu istilah umum yang mencakup variasi luasnya prosedur pemilihan responden. Convenience sampling merupakan pengumpulan informasi dari anggota populasi yang dengan senang hati bersedia memberikannya (Sekaran, 2011).

\subsection{Sumber dan Teknik Pengumpulan Data}

Sumber dan Teknik Pengumpulan Data yang digunakan dalam penelitian ini adalah data primer, yaitu data yang diperoleh atau dikumpulkan secara langsung dari sumber datanya melalui wawancara (interview) dan daftar pertanyaan (questionaire) yang diberikan kepada responden yang dijadikan sampel. Penelitian ini menggunakan survey untuk mendapatkan data-data yang diperlukan. Cara yang digunakan adalah dengan wawancara (interview) dan menyebarkan daftar pertanyaan (questionaire) kepada responden PT Perkebunan Milano Panai Tengah Labuhanbatu. Skala Pengukuran item pernyataan dari variabel-variabel penelitian menggunakan Skala Likert yang dilakukan dengan pembagian berikut: Sangat Setuju $(S S)=5$; Setuju $(S)=4$; Kurang Setuju $(\mathrm{KS})=3$; Tidak Setuju $(\mathrm{TS})=2$; Sangat Tidak Setuju $(\mathrm{STS})=1$.

Untuk mengukur instrumen penelitian ini, maka dilakukan uji validitas dan reliabilitas. Uji Validitas bertujuan untuk mengukur sah/valid tidaknya suatu kuesioner (Maholtra, 2009). Menurut (Ghozali, 2006) Suatu kuesioner dikatakan valid jika nilai loading factor variabel lebih besar dari 0,5 (0,5 > Sig.) Uji Reliabilitas adalah indeks yang menunjukkan suatu kuesioner dapat dipercaya atau tidak, (Ghozali, 2006). Suatu kuesioner dikatakan reliabel atau handal jika jawaban seseroang terhadap pernyataan adalah konsisten atau stabil dari waktu ke waktu. variabel dikatakan reliabel jika memberikan nilai cronbach alpha $(\alpha)$ lebih besar daripada 0,6. Untuk teknik analisis data dengan menggunakan SEM (Stuctural Equation Modelling) dengan program Smart PLS (Partial Least Square) yang memberikan gambaran jelas berhubungan antara konstrak penelitian. (Ghozali \& Latan, 2015) 


\section{Hasil dan Pembahasan}

\subsection{Hasil Uji Validitas dan Reliabilitas}

Hasil uji validitas pelatihan, disiplin kerja, remunerasi, motivasi berprestasi dengan kepuasan kerja sebagai variabel intervening terhadap kinerja karyawan pada penelitian ini adalah:

Tabel 1. Uji Validitas Convergent Validity

\begin{tabular}{|c|c|c|c|c|c|c|c|c|c|c|}
\hline $\begin{array}{l}\text { Pelatihan } \\
\left(\mathrm{X}_{1}\right)\end{array}$ & \multicolumn{2}{|c|}{$\begin{array}{l}\text { Disiplin Kerja } \\
\left(\mathrm{X}_{2}\right)\end{array}$} & \multicolumn{2}{|c|}{$\begin{array}{l}\text { Remunerasi } \\
\left.\mathrm{X}_{3}\right)\end{array}$} & \multicolumn{2}{|c|}{$\begin{array}{l}\text { Motivasi } \\
\text { Berprestasi } \\
\left(\mathrm{X}_{4}\right)\end{array}$} & \multicolumn{2}{|c|}{$\begin{array}{l}\text { Kepuasan } \\
\text { Kerja } \\
(\mathrm{Z})\end{array}$} & \multicolumn{2}{|c|}{$\begin{array}{l}\text { Kinerja } \\
\text { Karyawan } \\
\text { (Y) }\end{array}$} \\
\hline 0.884 & P6 & 0.694 & P12 & 0.707 & P17 & 0.729 & $\mathrm{P} 23$ & 0.549 & P27 & 0.665 \\
\hline 0.866 & P7 & 0,875 & P13 & 0.903 & P18 & 0.567 & P24 & 0.792 & P28 & 0,696 \\
\hline 0.823 & P8 & 0.802 & P14 & 0.921 & P19 & 0.795 & P25 & 0.714 & P29 & 0.657 \\
\hline 0.875 & P9 & 0.790 & P15 & 0.758 & $\mathrm{P} 20$ & 0.782 & P26 & 0.784 & P30 & 0.686 \\
\hline 0.679 & P10 & 0.687 & P16 & 0.915 & P21 & 0,673 & & & P31 & 0.687 \\
\hline & P11 & 0,664 & & & P22 & 0,550 & & & P32 & 0.524 \\
\hline
\end{tabular}

Sumber : Hasil Penelitian, 2017

Dari Tabel 1. Uji Validitas Convergent Validity diketahui bahwa semua Pernyataan (P1P32) memiliki convergent validity yang baik atau Valid karena nilai loading factor variabel lebih besar dari 0,5 (0,5 > Sig). Semakin tinggi nilai loading factor pada setiap konstrak menandakan semakin tinggi kontribusi indikator tersebut pada konstruk. Semakin tinggi nilai loading factor pada setiap konstrak menandakan semakin tinggi kontribusi indikator tersebut pada konstruk.

Untuk hasil uji reliabilitas penelitian mengenai pelatihan, disiplin kerja, remunerasi, motivasi berprestasi dengan kepuasan kerja sebagai variabel moderating terhadap kinerja karyawan adalah sebagai berikut:

Tabel 2. Uji Reliabilitas

\begin{tabular}{lll}
\hline & Composite Reliability & Cronbach's Alpha \\
\hline Pelatihan (X1) & 0.916 & 0.883 \\
\hline Disiplin Kerja (X2) & 0.886 & 0.844 \\
\hline Remunerasi (X3) & 0.925 & 0.897 \\
\hline Motivasi Berprestasi (X4) & 0.842 & 0.773 \\
\hline Kepuasan Kerja (Z) & 0.805 & 0.676 \\
\hline Kinerja Karyawan (Y) & 0.817 & 0.732 \\
\hline
\end{tabular}

Sumber : Hasil Penelitian, 2017

Sebuah model dikatakan reliabel apabila memiliki nilai composite reliability diatas 0,70 . Dari hasil pengolahan data (Tabel 2 Uji Reliabilitas), nilai composite reliability variabel Pelatihan, Disiplin Kerja, Remunerasi, Motivasi Berprestasi, Kepuasan Kerja dan Kinerja Karyawan secara berurutan adalah $0.916 ; 0.886 ; 0.925 ; 0.842 ; 0.805$ dan 0.817 . Keenam nilai tersebut adalah diatas 0,70 . Sedangkan untuk nilai cronbach's alpha, semua konstruk memiliki nilai di atas 0,60 yaitu $0.883 ; 0.844 ; 0.897 ; 0.773 ; 0.676 ; 0.732$ Dapat disimpulkan bahwa model memiliki reliabilitas yang baik. 


\subsection{Hasil Uji Hipotesis}

Uji hipotesis menggunakan software SmartPLS untuk melakukan uji hipotesis. Uji yang dilakukan adalah evaluasi inner model dan uji t untuk menjawab ketujuh hipotesis yang ada. Berikut adalah hasil uji hipotesis yang telah dilakukan dengan Model Signifikan:

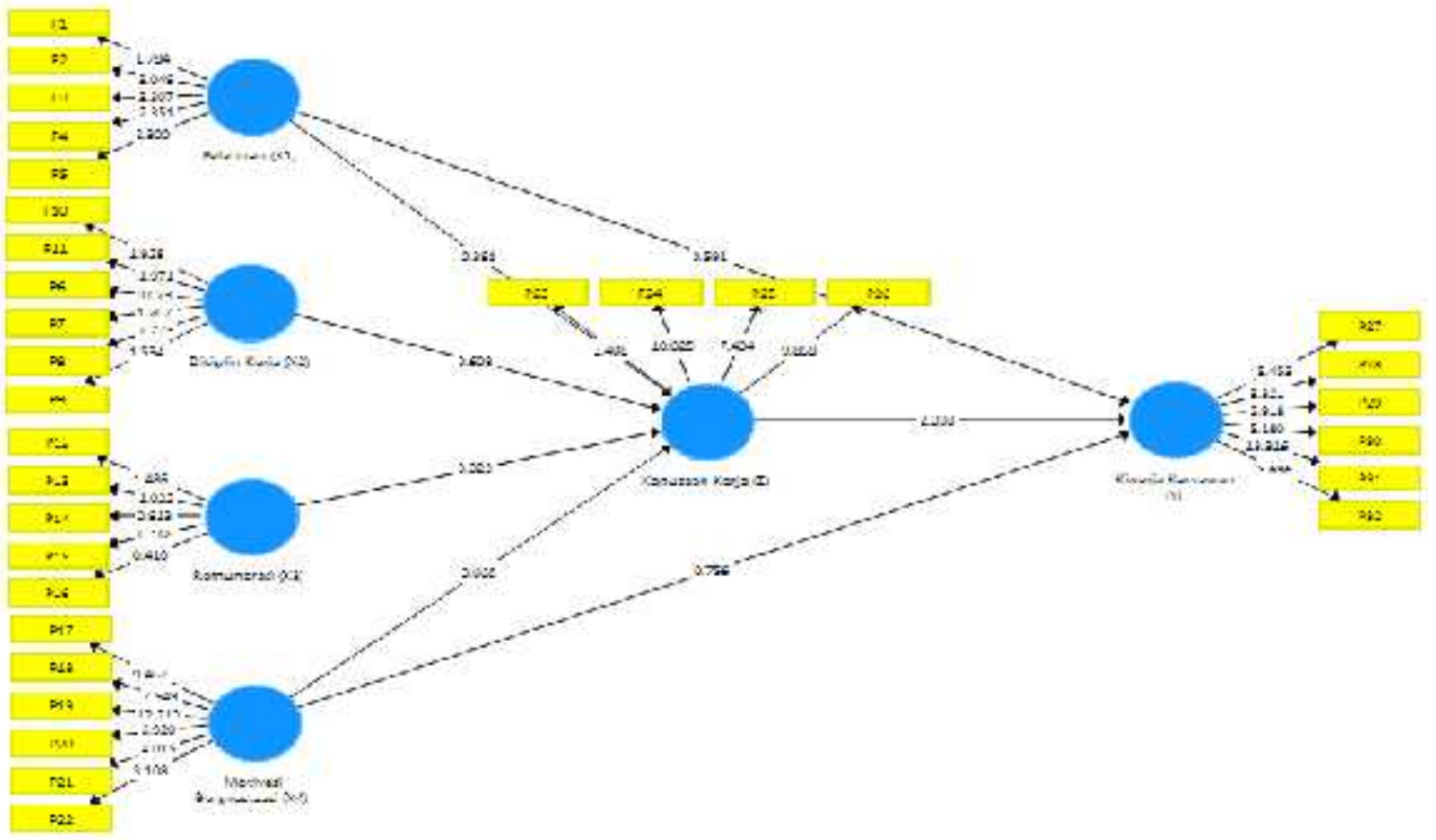

Gambar 2. Model Signifikan

Pengujian terhadap Model Signifikan dilakukan dengan melihat Nilai $R$ square yang merupakan uji goodnees-fit model sebagai berikut:

\begin{tabular}{ll}
\multicolumn{2}{c}{ Tabel 3. Nilai $R$ square } \\
\hline & $R$ Square \\
\hline Kepuasan Kerja $(\mathrm{Z})$ & 0.678 \\
\hline Kinerja Karyawan $(\mathrm{Y})$ & 0.612 \\
\hline Sumber : Hasil Penelitian, 2017 &
\end{tabular}

Dari Tabel 3. Nilai $R$ square diketahui bahwa variabel kinerja karyawan $\left(\mathrm{Y}_{2}\right)$ dan kepuasan kerja $(\mathrm{Z})$ dapat dijelaskan oleh variabel Pelatihan $\left(\mathrm{X}_{1}\right)$, Disiplin Kerja $\left(\mathrm{X}_{2}\right)$, Remunerasi $\left(\mathrm{X}_{3}\right)$, dan Motivasi Berprestasi $\left(\mathrm{X}_{4}\right)$ sebesar 67,8\%, dan 61,2 \%. Untuk Uji Kesesuain Model (Uji goodness of fit) menggunakan persamaan Q-square berikut :

$\mathrm{Q}^{2}=1-(1-$ Kepuasan Kerja ) (1- Kinerja Karyawan)

$=1-(1-0,678)(1-0,612)$

$=1-(0,322)(0,388)$

$=0,875$. Dengan demikian nilai $\mathrm{Q}^{2}=0,875>0$ yang berarti model memiliki kesesuaian. 
Tabel 4. Path Coefficients

\begin{tabular}{ll}
\hline & $\begin{array}{l}\text { T Statistics } \\
(|\mathrm{O} / \mathrm{STDEV}|)\end{array}$ \\
\hline Pelatihan $\left(\mathrm{X}_{1}\right)->$ Kepuasan Kerja $(\mathrm{Z})$ & 0.391 \\
\hline Disiplin $\left(\mathrm{X}_{2}\right)->$ Kepuasan Kerja $(\mathrm{Z})$ & 0.608 \\
\hline Remunerasi $\left(\mathrm{X}_{3}\right)$-> Kepuasan Kerja $(\mathrm{Z})$ & 0.023 \\
\hline Motivasi Berprestasi $\left(\mathrm{X}_{4}\right)$-> Kepuasan Kerja $(\mathrm{Z})$ & 9.668 \\
\hline Pelatihan $\left(\mathrm{X}_{1}\right)->$ Kinerja Karyawan $(\mathrm{Y})$ & 0.591 \\
\hline Motivasi Berprestasi $\left(\mathrm{X}_{4}\right)$-> Kinerja Karyawan $(\mathrm{Y})$ & 0.756 \\
\hline Kepuasan Kerja $(\mathrm{Z})->$ Kinerja Karyawan $(\mathrm{Y})$ & 2.038 \\
\hline
\end{tabular}

Sumber : Hasil Penelitian, 2017

Pengujian hipotesis yang diajukan, dapat dilihat dari besarnya nilai t-statistik. Batas untuk menolak dan menerima hipotesis yang diajukan adalah $\pm 1,96$, dimana apabila nilai $t$ berada pada rentang nilai -1,96 dan 1,96 maka hipotesis akan ditolak atau dengan kata lain menerima Ho. Berdasarkan hasil uji-t dengan taraf nyata 0,05 diketahui pengaruh Pelatihan $\left(\mathrm{X}_{1}\right)$ terhadap Kepuasan Kerja $(Z)$ adalah (0.391 lebih kecil dari t-tabel 1,96), pengaruh Disiplin $\left(\mathrm{X}_{2}\right)$ terhadap Kepuasan Kerja (Z) adalah (0.608 lebih kecil dari t-tabel 1,96), pengaruh Remunerasi $\left(\mathrm{X}_{3}\right)$ terhadap Kepuasan Kerja (Z) adalah (0.023 lebih kecil dari t-tabel 1,96) pengaruh Motivasi Berprestasi $\left(\mathrm{X}_{4}\right)$ terhadap Kepuasan Kerja (Z) adalah (9.668 lebih besar dari t-tabel 1,96), pengaruh Pelatihan $\left(\mathrm{X}_{1}\right)$ terhadap Kinerja Karyawan $(\mathrm{Y})$ adalah $(0,591$ lebih kecil dari t-tabel 1,96) pengaruh Motivasi Berprestasi $\left(\mathrm{X}_{4}\right)$ terhadap Kinerja Karyawan (Y) adalah (0.756 lebih kecil dari t-tabel 1,96), pengaruh Kepuasan Kerja (Z) terhadap Kinerja Karyawan (Y) adalah (2.038 lebih besar dari t-tabel 1,96).

Dari Tabel 4. Path Coefficients variabel Kepuasan Kerja (Z) -> Kinerja Karyawan (Y) memiliki pengaruh positif dan signifikan dengan nilai t statistik sebesar 2.038. Pengaruh variabel yang paling dominan adalah Motivasi Berprestasi $\left(\mathrm{X}_{4}\right)->$ Kepuasan Kerja (Z) dengan nilai $\mathrm{t}$ statistik sebesar 9.668. Hal ini juga menunjukkan bahwa Motivasi Berprestasi $\left(\mathrm{X}_{4}\right)$ memiliki pengaruh positif dan signifikan terhadap Kepuasan Kerja (Z)

\section{Kesimpulan}

Berdasarkan hasil pembahasan dalam penelitian ini maka kesimpulan penelitian ini sebagai berikut : a) Pelatihan berpengaruh positif dan tidak signifikan terhadap Kepuasan Kerja. Hal ini dapat diketahui dari nilai $t$ statistics lebih kecil dari 1,96 yaitu 0,391, b) Disiplin berpengaruh positif dan tidak signifikan terhadap Kepuasan Kerja. Hal ini dapat diketahui dari nilai $t$ statistics lebih kecil dari 1,96 yaitu $0,608, c)$ Remunerasi berpengaruh positif dan tidak signifikan terhadap Produktivitas Kerja. Hal ini dapat diketahui dari nilai $t$ statistics lebih kecil dari 1,96 yaitu 0,023, d) Motivasi Berprestasi berpengaruh positif dan signifikan terhadap Kepuasan Kerja. Hal ini dapat diketahui dari nilai $t$ statistics lebih besar dari 1,96 yaitu 9,668 , e) Pelatihan berpengaruh positif dan tidak signifikan terhadap Kinerja Karyawan. Hal ini dapat diketahui dari nilai $t$ statistics lebih kecil dari 1,96 yaitu 0,591,f) Motivasi Berprestasi berpengaruh positif dan tidak signifikan terhadap Kinerja Karyawan. Hal ini dapat diketahui dari nilai $t$ statistics lebih kecil dari 1,96 yaitu 0,756, g) Kepuasan Kerja berpengaruh positif dan signifikan terhadap Kinerja Karyawan. Hal ini dapat diketahui dari nilai $t$ statistics lebih besar dari 1,96 yaitu 2,038. 


\section{Saran}

Agenda penelitian selanjutnya perlu dilakukan penelitian-penelitian sejenis untuk tipe-tipe perusahaan lain yang belum tergambarkan dan mengamati Pendidikan para karyawan, lingkungan internal perusahaan sebagai variabel yang dapat memperkuat hubungan terhadap prestasi kerja karyawan.

\section{Ucapan Terimakasih}

Terimakasih kami sampaikan kepada Lembaga Penelitian dan Pengabdian kepada Masyarakat Sekolah Tinggi Ilmu Ekonomi (STIE) Labuhanbatu Rantau Prapat atas dukungan dana yang diberikan sehingga penelitian ini bisa terlaksana

\section{Daftar Pustaka}

Arikunto, S. 2012. Prosedur Penelitian Suatu Pendekatan Praktek. Yogyakarta :Rineka Cipta. De Pora Antonio. 2011. Remunerasi (Kompensasi dan Benefit). Jakarta : Penerbit Rana Pustaka. Dessler, Gary, 2009. Manajemen Sumber Daya Manusia. Jakarta: Indeks.

Gomes, Faustino Cardoso, 2003. Manajemen Sumber Daya Manusia, Edisi Pertama, Cetakan Kelima, Yogyakarta : Andi Offset.

Ghozali, Imam, 2006. Aplikasi Analisis Multivariate dengan program SPSS. Semarang: Badan Penerbit Universitas Diponegoro.

Ghozali, Imam, dan Latan Hengky 2015. Partial Least Square Konsep, Teknik, dan Aplikasi menggunakan Program SmartPLS 3.0 Semarang: Badan Penerbit Universitas Diponegoro.

Handoko, T. H. 2012. Manajemen Personalia dan Sumber Daya Manusia. Yogyakarta: BPFE.

Ivancevich, John M, Robert Konopaske dan Michael T Matteso, 2009. Perilaku dan Manajemen Organisasi, Edisi Ketujuh, Jakarta : Erlangga.

Malhotra, Naresh K. 2009, Basic Marketing Research: A Decision-Making Approach, third edition, New Jersey: Prentice-Hall, Pearson Education Inc. Upper Saddle River.

Mangkunegara, Anwar Prabu. 2007. Sumber Daya Perusahaan. Bandung: Remaja Rosdakarya.

Sekaran, Uma. 2011. Research Methods for business Edisi I and 2. Jakarta: Salemba Empat.

Sugiyono. 2011. Metode Penelitian Kuantitatif, Kualitatif dan R\&D. Bandung: Afabeta.

Syamsuri, Abd. Rasyid, 2012, Analisis Pengaruh Pendidikan, Pengawasan Kerja dan Disiplin terhadap Kinerja Pegawai Dinas Pendidikan Kabupaten Mandailing Natal', Tesis, Universitas Sumatera Utara. 